\title{
The role of historical green spaces in the identity and image of today's cities: The case of Madrid
}

\author{
Eva J. Rodríguez Romero, Carlota Sáenz de Tejada Granados, Rocío \\ Santo-Tomás Muro \\ Departamento de Arquitectura y Diseño. Universidad CEU San Pablo. Escuela Politécnica \\ Superior. Spain \\ E-mail: rodrom@ceu.es, carlota.saenztejada@ceu.es, rocio.santotomasmuro@beca.ceu.es
}

\begin{abstract}
The image that a city offers when approaching it, depending on its topographical situation, the drawing of its borders or its urban form, generates a perceptive construction, for both locals and tourists, with the potential to become an iconic image and therefore play a part in the collective imagery. The character and value of those landscapes is largely determined by their green spaces, preserved in most European cities for their ecological or historical significance. Being able to recognize the worthiness of these proximity visions, in the context of today's growing cities, is of fundamental relevance in order to enhance the sense of place, amongst other community values. In this communication, we study the above-mentioned aspects in the image of the city of Madrid, within the framework of the project 'Proximity landscapes of the city of Madrid. From the 19thC to the present' currently in process. Through a landscape analysis of a selection of iconographic representations of the surroundings of the city, we draw special attention to the presence of historical green spaces throughout time, and its relation with architectural landmarks in the progressive construction of an iconic image of the city. From here, we can deduce the relevance that these elements have in the generation of a recognizable character and the decisive role of protection mechanisms in order to preserve it.
\end{abstract}

Keywords: landscape history, proximity landscape, city iconography, sense of place, Madrid.

\section{Introduction}

The urban fabric grows in a way that adapts or transforms the existing topography, which makes the city contour a changing figure throughout history. This urban contour is not a defined line, but a fringe where city and country collide (Sorokin, Zimmerman, 1929). In this area where rural and urban converse, spaces from the urban structure intertwine with elements of land management, cultivation areas, suburban farms, woods and fields, etc. (Rodríguez, 2011), becoming, over the ages, defining elements of the image of the city. We can consider this fringe as 'proximity' landscapes: landscapes that are perceived when the city is either a destination or a point of departure.

The image that a city offers when approaching it, depending on its topographical situation, the drawing of its borders or its urban form, generates a perceptive construction, for both locals and tourists, with the potential to become an iconic image and therefore play a part in the collective imagery. Just as we see the historical architecture of our cities, the cultural heritage, as 'memory containers'... landscape, open spaces and views should be considered heritage elements as well (Cano, 1985) and therefore generators of meaning and identity for the city. 
The character and value of border landscapes is largely determined by their green spaces, preserved in most European cities for their ecological or historical significance. In the case of the city of Madrid, besides the suburban farms from medieval times, the presence of the Royal Places close to the capital since the Spanish Hapsburg dynasty has played a significant role. Both pre-existing conditions of the site evolved throughout time transforming into public green spaces that are nowadays part of the city's network of parks and open spaces. Being able to recognize the worthiness of these proximity visions, in the context of unceasing urban growth and transformation, is of fundamental relevance in order to enhance the sense of place, amongst other community values, in line with the actual trends of urban greening (Urbano, 2013).

In this communication, we study certain aspects in the image of the city of Madrid, within the framework of the project 'Proximity landscapes of the city of Madrid. From the 19th Century to the present' currently in process. Firstly, we make a general overview of the transformation processes in the most relevant periods of the city's history from a morphological perspective, locating the most significant green spaces in said process. Then, we analyze the presence of these parks and fields and their characteristic features in a selection of iconographic representations of the city, drawings and views (depicted by painters, geographers and architects), to end with a valorization of the historical green spaces inside the current network of green spaces of Madrid.

\section{Methodology}

We undertake a critical analysis of historical cartography (among other documentary evidence) to detect landscape patterns, structural elements and areas of urban-rural dialogue along Madrid's contour line. This is done in four relevant stages of the city's development: early 19th century (before its first urban enlargement plan), late 19th century, mid-20th century, and the present time. The evolutionary analysis allows to detect the permanence of certain relevant green spaces, playing a key role in the shaping of the periurban landscape of the city.

The historical plans used as basis for these graphical analyses are 1809, 1877-81, 19401976 and 2010, all retrieved from the database "Planea" (Autonomous Community of Madrid 2017). The main roads to access the city (which provide perceptive lines of interest), the lookouts and the green spaces are highlighted in this analysis.

For the study of the above-mentioned aspects of the image of the city of Madrid, we make a landscape analysis of a selection of iconographic representations of the surroundings of the city, drawing special attention to the presence of historical green spaces throughout time, and their relationship with architectural landmarks in the progressive construction of an emblematic image of the city.

\section{The green spaces of Madrid throughout History}

Medieval Madrid settled over a rugged, hilly terrain, east of the Manzanares river course. The dells formed by its streams determined the direction of the main streets; footprints which we can still find in the city's urban morphology of today. A succession of walls and taxation fences girded the city center up to the late 18th Century. The demolition of the last fence, commanded by Philip II in 1625, began in the mid-19th Century to undertake the enlargement plan.

Regarding the surroundings of the city, until 1900 Madrid had numerous orchards in the urban contour, but one could also find them inside the walls, as reflected in historical cartography, chronicles, stories of the city and travel books (Rodríguez, 2011). The abundance of these orchards and gardens endowed the city with a certain character, in close relation to its surrounding countryside. The considerable number of country houses that appeared in the periphery (along the main roads, especially in certain rural cores near the "Villa de Madrid") were also key elements in the composition of 
the city's peri-urban landscape (Lasso de la Vega, 2007). These country houses, despite their productive origin, played a fundamental role as recreational spaces; for the nobility's use at first, and later for the bourgeoisie's as well.

During the 18th Century, the surroundings of the Royal Palace were landscaped and urbanized (Martínez, 2008), bridges and monumental gates were built in the perimeter of the city (Ortega, Martínez \& Marín, 2008), as well as tree-lined promenades in the proximity of the river, designed for the public's recreation and aiming to confer a monumental look to the accesses to the city. For the first time, there was a conscious decision of putting value into the city's exterior image. The restocking and lining of the urban greenery in the contour starts to be regulated, as a precursor of the future 19thcentury transformations. The main entrances to the city were the road from the Guadarrama mountain range in the northwest (from the El Pardo Royal Place to Madrid), Extremadura road from the west, Alcalá de Henares road from the east, and Toledo road from the south. These were 'Royal paths'; cobbled, wide and properly treated, suitable for saddles ('horseshoe roads'). The north access, from Burgos, was the only one suitable for carriages ('wheel paths') (Terán, 2006). Important green urban limits were sited to the west (Casa de Campo, El Pardo mount and la Florida promenade along the river) and to the east (the Buen Retiro Royal Place). Of all these green areas, only the Buen Retiro was incorporated inside the city walls, however they were all, except for the Florida promenade, to be used solely by the Crown. Therefore, the public only had access to outside walkways, the river banks, and some private gardens of the suburban farms as vegetated open spaces (Figure 1). The spaces from where one could contemplate the city and its immediate vicinity were mainly located along the northeast access, following the course of the river, and in the soft hills of the surroundings of the Alcalá and Valencia paths (Rodríguez, Sáenz de Tejada, 2016).

In the times of Ferdinand VII, urban transformations (Oriente and Armería Squares, Viaduct of Bailén Street, 'Cuesta de la Vega') created a new visual connection along the 'Cornice', from the Royal Palace to the San Francisco el Grande Basilica. At the same time, works were done to upgrade the Royal Places of the periphery, the river was channeled in its pass through the city, and the exterior promenades were improved and enhanced with the planning of both Pirámides roundabout to the south and Fuente Castellana Avenue to the north. The latter embodied the vertebral axis along which the city would grow. Meanwhile, the south area outside the walls was populated with warehouses and industrial buildings that, from the mid-19th century onwards, proliferated around the railway tracks and stations (and especially around the bypass linking them). Towards the mid-19th Century, all important roads (Guadarrama, Burgos, Extremadura, Alcalá, Valencia, Toledo and Aranjuez) were already "Royal roads", and the lookouts from where the city could be perceived as a whole were the same as those from the beginning of the century.

The transformation of the Castellana promenade in the main entrance to the city from the north was first proposed in Carlos $\mathrm{M}^{\mathrm{a}}$ de Castro's preliminary project for the enlargement plan of the city of Madrid, in 1857. In this project, blocks would be extended in a half-crown shape to the north and east of the city center; an idea that Zuazo and Jansen would later pick up in their proposal of a northsouth structural axis for the future growth of the city in the International Competition of 1929 (Pinto, 2001).

In the mid-20th Century, Madrid annexed many of the rural cores surrounding the city center throughout the two decades after the Spanish Civil War. The urban fabric would then start, during the second half of the 20th Century, to fill in the voids. However, this urban growth would be respectful of both Casa de Campo and El Pardo Mount, Madrid's major 'green lungs'. Thanks to the preservation of these two elements, the city's north and west peri-urban landscape upholds, up to today, its natural character (Figure 2). Nuñez Granés designed in 1909, commissioned by the Town Hall, a "Periphery Management Plan", extended across the whole surface of the municipal boundary, in a way that the small hubs of 

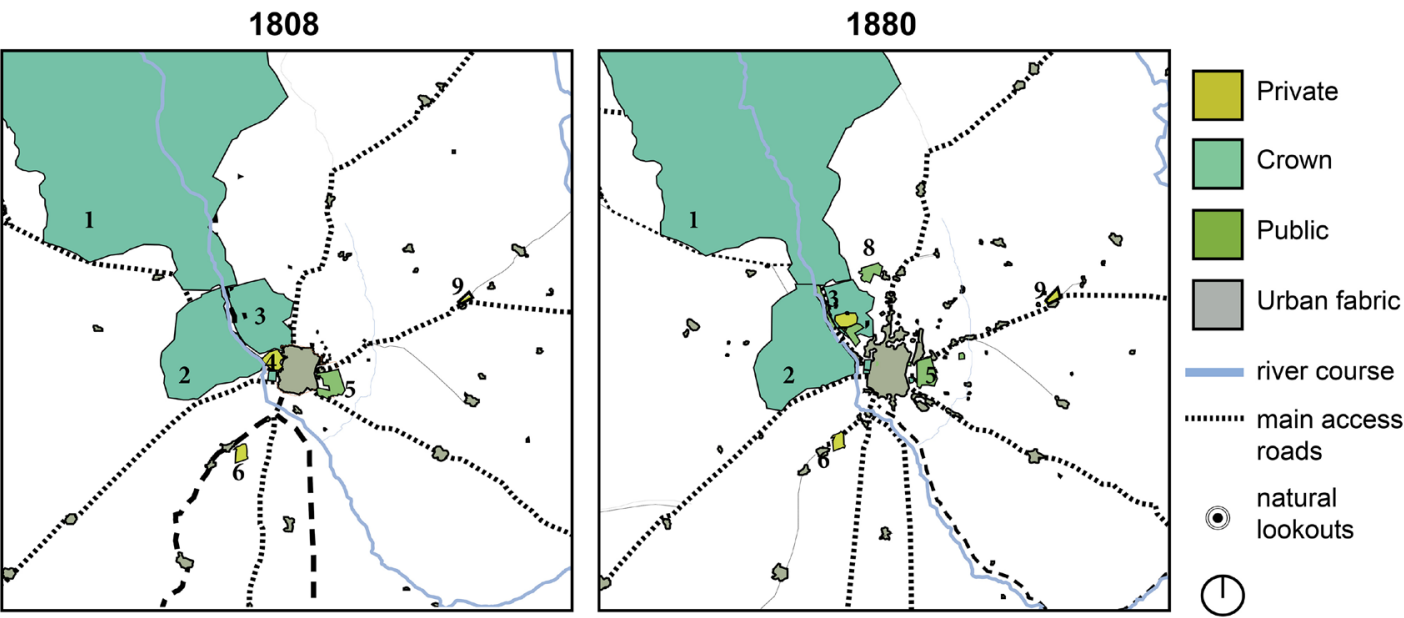

1. El Pardo 2. Casa de Campo 3. La Florida-Moncloa 4. Principe Pio Mountain 5. El Retiro

6. Vista Alegre 7. Parque del Oeste 8. Dehesa de la Villa 9. El Capricho

Figure 1. Historical green spaces and its evolution in the city of Madrid, 19th Century.

1976

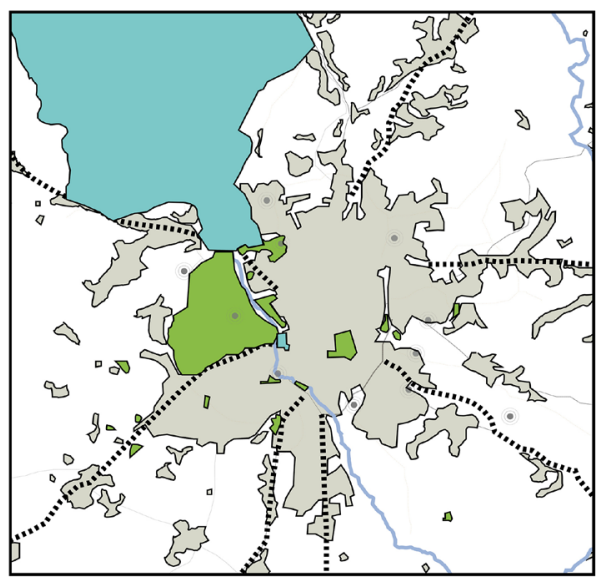

2010

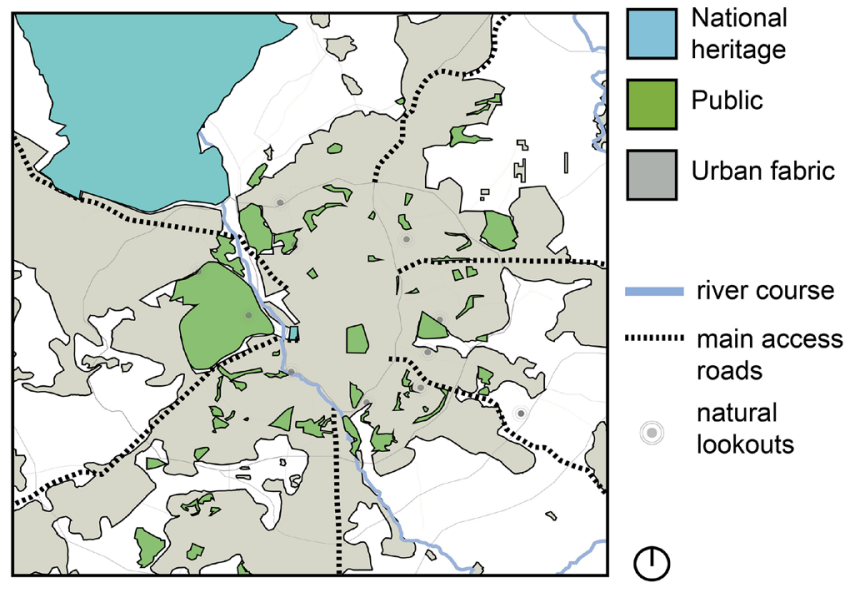

Figure 2. Historical green spaces and new developments in the city of Madrid 20th-21th Centuries.

working population scattered around Madrid became incorporated in the general structure of the enlargement, still with great voids in its construction (Pinto, 2001). It created a new belt that connected the outskirts' urban cores (between each other, and with the city center) by means of large 'arteries', distributing the main uses. El Pardo was presented as an urbanized park for the upper class, and to the east there was working-class housing and industrial land. Between the enlargement, the small cores and the former colonies, wide parks and green areas were disposed. Although not completed, it had a profound influence in the subsequent urban formulations prior to the Civil War.
In the first half of the 20th Century, the national and community roadway system was established, similar to the current one, being the six national roads the principal accesses of Madrid. The city has grown so much that most of its lookouts have been incorporated inside the urban mesh, and only from the farthest can the city be perceived as a whole (Rodríguez, Sáenz de Tejada, 2016). Regarding the open spaces, El Retiro (renamed as Park of Madrid) and Casa de Campo became property of the municipality in 1868 and 1931 respectively. In the late 19th century, the Oeste Park was built ex novo, acting as a link to the last part of the city's enlargement with the Royal Possessions of the 
Principe Pio Mountain and Moncloa. In the early 20th Century, over a sizeable proportion of Moncloa's grounds, the university campus was erected. Conceived as a garden-city, as a transitional space towards Casa de Campo and El Pardo, it would help preserve the ecological and landscape values of the northwest part of the city, as well as ensuring the perception of the iconic view of the 'Cornice' from the west (although this was strongly altered by the urbanization of the riversides). The silting of the shore with buildings in the 20th Century (especially in the south's right margin) blurred the view of the city that painter Francisco de Goya depicted in his design for a tapestry from San Isidro's meadow.

Since the end of the 19th Century, the development of public parks, with green areas and leisure facilities, was a primary goal of both the municipal authorities and private enterprises, where the known as 'recreational gardens' emerged as parks exclusively devoted to recreational activities. Some of the most relevant examples of this are Las Delicias, El Tivoli, Apolo, Buen Retiro (in Cibeles), the Eliseo Madrileño in today's Fuente del Berro, the Oriental Gardens, the Parisiana in Moncloa (in the area of San Bernardino), and the Portici in the River Manzanares. Renovations were also made in El Retiro, creating the 'Beasts House', the 'Car Walks' and the 'Cow's house'. Similarly, there was a 'Leisure Center' in Madrid's development company in the Linear city of Arturo Soria. All these actions followed hygienist programs, with gardens and sport facilities that equipped the neighborhoods with green open spaces, becoming a general trend throughout the 20th century.

\section{The green spaces in the city iconography of Madrid}

The steep cut produced by the River Manzanares generates the city's west façade, the 'Cornice'. The preservation of large Royal possessions such as the El Pardo Mount, Casa de Campo, Campo del Moro, and the riversides, endowed the view with broad masses of trees and greenery. Alongside, the architectural sturdiness was provided by the great mass of the Royal Palace and the powerful dome of San Francisco el Grande Basilica, over a backdrop of smaller domes and towers. To the left of this ensemble, the towers of Plaza de España (built as emblems of modernity in the mid-20th Century) have become indispensable to the 'Cornice' of today.

This is the iconic image of Madrid, and has been represented from the right-side riverbank by uncountable artists throughout the years. From the comparison of several paintings and today's views we can identify the evolution and permanence of certain elements and assess the important presence of the historical green spaces.

In the view painted by Antonio Jolie in the late 18th Century (Figure 3), we appreciate a peri-urban landscape that would remain similar up to the mid-19th Century. The architectural elements perched above the cliff offered an image of power and representativeness while the uses below, at the riverside level, were mainly residual; orchards, public washing facilities and small factories serving the city, however not considered worthy of being inside its boundaries. In Brambilla's 19th Century view (Figure 4), the same elements arise, but with a growth of the foliage of the wooded areas and a sharper representation of landmark buildings such as the Royal Palace and the scattered popular architecture of the laundries and industrial buildings near the river, intentionally showing the contrast between the formal city and its surroundings. In these representations, the green element provided by the vegetation located in the traditional treelined promenades (where the trees were now starting to become well-grown) and the Royal Possession's gardens act as a frame to highlight the architectural landmarks.

The section of the River Manzanares passing through the city was channeled in the first half of the 20th Century, while Segovia Bridge, rebuilt after the Civil War, is still today an important access to the city center. The view of Madrid from this point, looking to the south, has been subjected to interference by buildings that filled the right margin of the river along the 20th century (Figure 5). The decline of the green areas endangered the inherited image of the urban landscape configuration. 

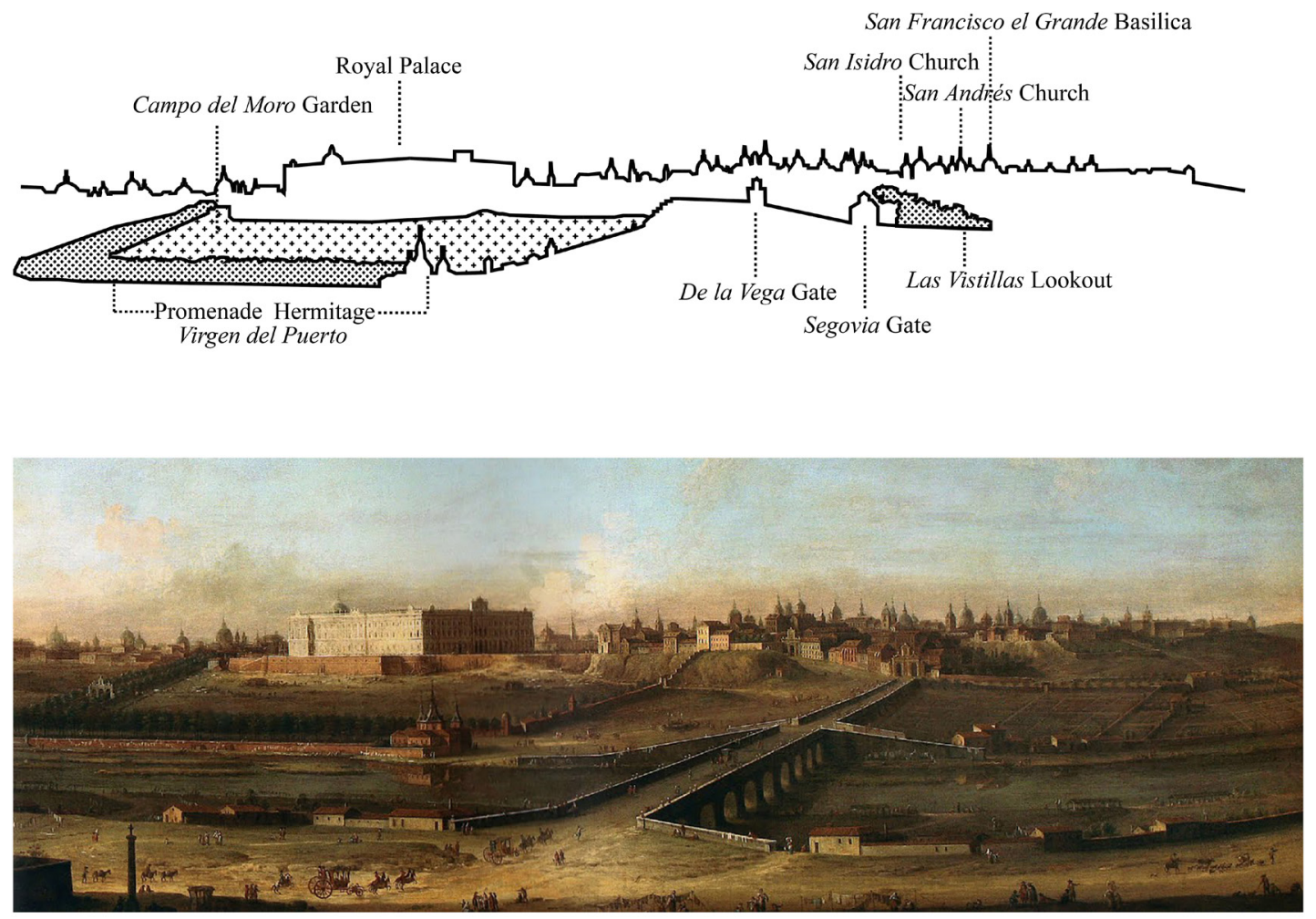

Figure 3. Landscape analysis of the painting Vista de Madrid by Antonio Jolie (ca. 1750).
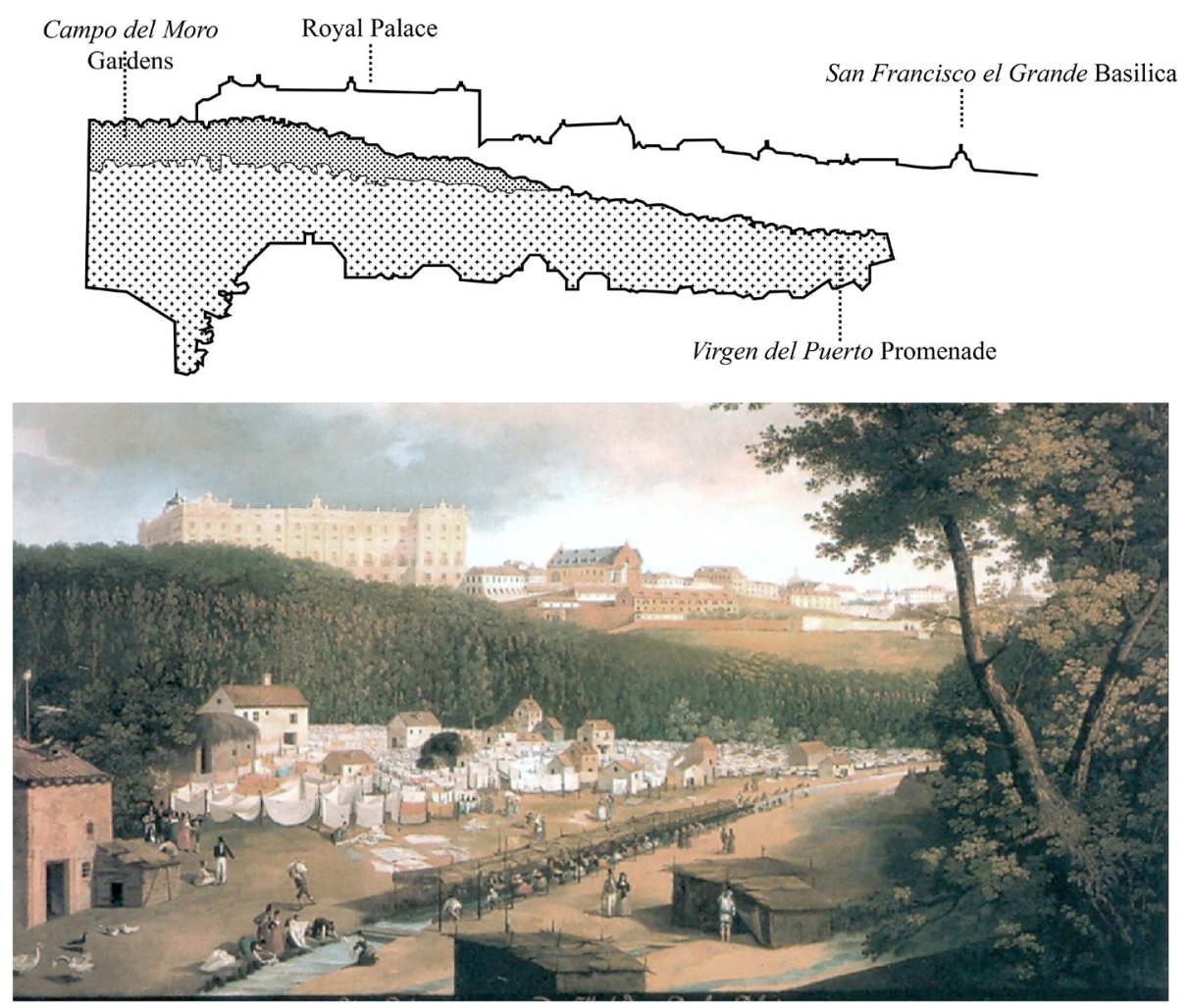

Figure 4. Landscape analysis of the painting Vista del río con parte de Madrid y Real Palacio by Fernando Brambilla (ca. 1830). 

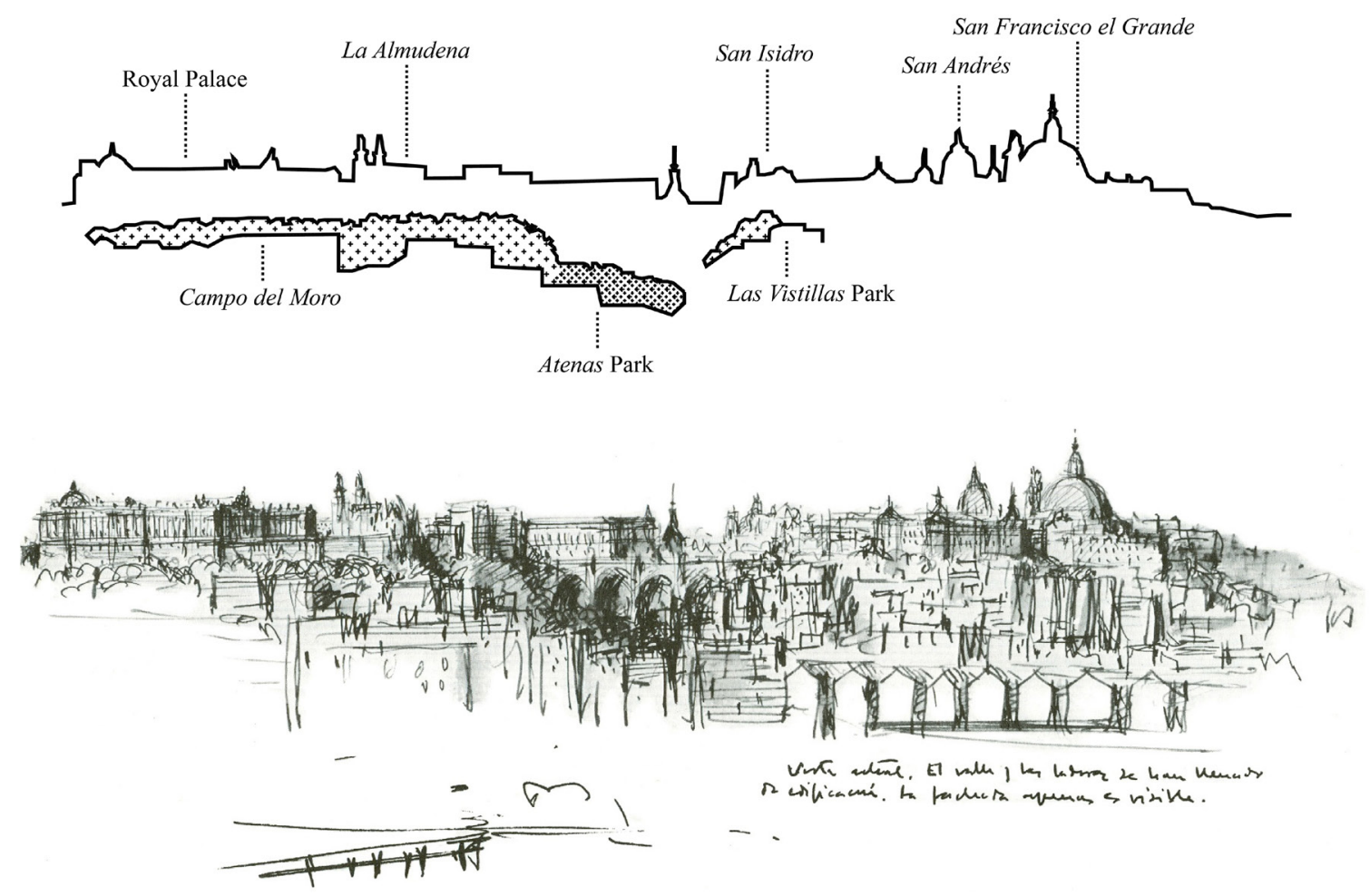

Figure 5. Landscape analysis of the drawing "Cornisa" de Madrid by Julio Cano Lasso (ca. 1980).

The green spaces of Madrid today and the role of the historical ones in the public space

The sensibility towards landscape features and views of the city is nothing new, but with the emergence of the urban landscape concept, and especially with the recent historical urban landscape concept (Velasco, 2010) (as a counterpoint to the 'generic city'), the importance of considering landscape values within the contemporary urban planning techniques has been revealed (Zárate, 2011). This is mainly because of its potential to generate and preserve the character of the cities. Landscape and its unique elements become a paradigm of balance between heritage, urban development, land occupation and sustainability (Cruz, Español, 2009; Zoido, 2002). It is essential to maintain these remarks, especially in the peripheral visions of the city; and area easily devalued in its cultural and natural issues (Wester-Heber, 2004). Preserving the historical urban landscapes is as important as valuing the everyday landscapes that any citizen or tourist navigates while approaching the city, preventing them from becoming wastelands with industrial and residual canisters.

Madrid, and especially its surrounding landscape, has strongly evolved since its medieval state. However, the permanence of certain key elements on its west and southwest side (such as the historical green spaces and the architectural landmarks) guarantees the role of this historical landscape in the collective imagery of the city.

Recent works have been integrated in the design of Madrid Rio, an Urban Renewal Plan (2008-2010). Taking great part of the M-30 ring-road underground allowed for the design of a large green urban corridor along the riversides. In this way, whereas before there was a stronger contrast between the city and its river, today the river is fully integrated in the city life. Projects like this, that focus their attention on the green open spaces to 
make the city appealing to the pedestrian, along with architectonic interventions like the Royal Collections Museum, contribute to the restoration of the historical memory of the urban image and green open spaces by the riverside (Figure 6). Green areas and views are integrated in a system of open spaces designed at a metropolitan scale. These historical spaces should not be left isolated, as often happened with the creation of new urban parks. Consistency between historical parks, urban promenades and new parks in a wide spatial context, at an urban and metropolitan scale, is deemed necessary to maintain the legibility of the landscape, building on the capacities of said landscape to tell the story of the site, enhancing its identity and integral value (Antrop, 2005).

\section{Conclusion}

Within the urban landscape, the contour of the urban fabric (fringes between remnants of natural and artificial) is where the landscape is particularly sensitive and vulnerable. The distant or progressive vision when approaching a city, as in the case of Madrid, becomes part of its identity. This is reflected, for instance, in the views of the 'Cornice'. This fact reflects the importance of preserving certain ensembles, including the historical green spaces, and not only the architectural elements.

Madrid strongly changed its image since the mid-19th Century with the bourgeois enlargement, as well as after the Civil War in the 20th Century. However, vestiges and footprints of former agricultural spaces and gardens remain, as well as traces of the successive concentric urban growths. Throughout this process of growth and transformation, the surrounding landscape has also evolved, though the city's geographical and topographical situation, still today, provides views of great character and significance.

It becomes apparent that preserving the landscape value of urban environments is a
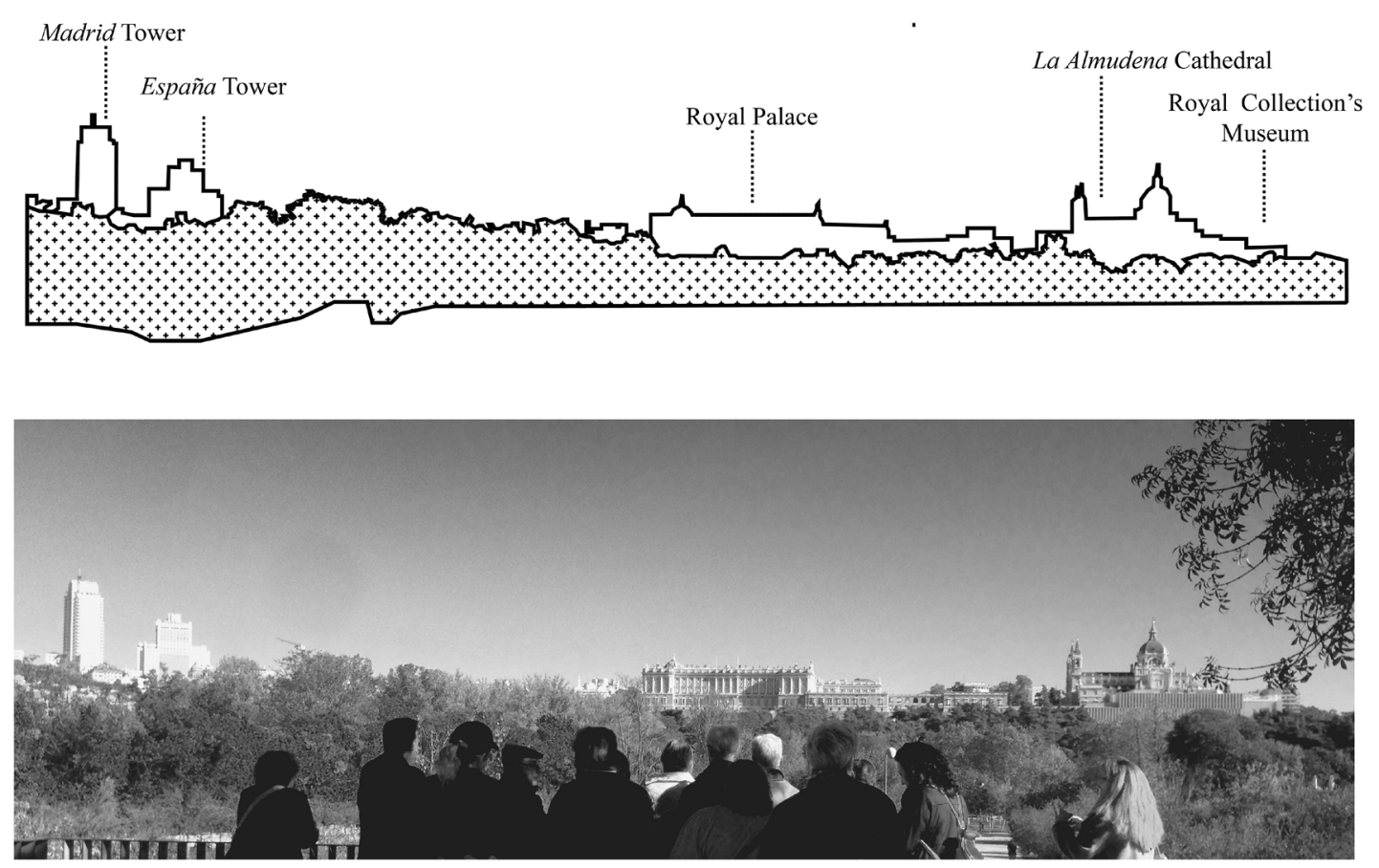

Figure 6. View of the 'Cornice' of Madrid from the Huerta de la Partida lookout, in Casa de Campo, 2017. 
complex issue and memory in the urban and landscape field should be based on respect for both the historical and natural processes, focusing on the green spaces (inherited or contemporary) for their ability to combine both natural and historical facets and provide a strong environmental character to the perceptions that the city offers.

As important as preserving the historical urban landscape of the urban historical centers, is to value the everyday 'proximity landscapes', the access landscapes, the medium-scale views and the complex spatial relations arising from the overlapping of periods. Landscape should be enjoyed, lived, but it is also witness of the history and memory of the city. Being able to recognize the worthiness of these proximity visions, in the context of today's growing cities, is of fundamental relevance in order to enhance the sense of place, amongst other community values. We can deduce the relevance that the green spaces have in the generation of a recognizable character and the decisive role of protection mechanisms to preserve it in urbanregeneration actions and in new urban growth plans.

Landscape perception, with all its complexity and historical load, can activate the memory; where the past experience lives and where we can identify the character of a place. Thus, gazing upon the city's views, the relation between urban and rural in the periurban space, as well as the views from inside the city towards the countryside, should not be circumstantial factors left to chance, but a fundamental heritage element to consider as a design component in the interventions in contemporary cities. The calling of urban open spaces, what they are destined to be, is a consequence of what they have been; but at the same time, certain elements of the urban identity of the past should be preserved in a way that they can integrate new elements of the identity of the future.

\section{Acknowledgements}

This research has been developed in the framework of the State Plan Project of the Ministry of Economy and Competitiveness
(HAR2014-57843-R), entitled "Proximity Landscapes of the City of Madrid. From the 19th Century to the present". We thank the General Secretariat of Science, Technology and Innovation for the funding of this project.

Likewise, we thank the Spanish Ministry of Education for the pre-doctoral scholarship (FPU14/05524) granted to co-author Carlota Sáenz de Tejada Granados in its FPU Program.

Lastly, we thank San Pablo-CEU University Foundation for the pre-doctoral scholarship granted to co-author Rocío Santo-Tomás Muro in its FPI Program.

\section{References}

Antrop, M. (2005) 'Why landscapes of the past are important for the future', Landscape and Urban Planning 70 (1-2) 21-34.

Autonomous Community of Madrid (2017) Planea (http://www.madrid.org/planea). Accessed 6 May 2017.

Cano Lasso, J. (1985) La ciudad y su paisaje (Author's edition, Madrid).

Cruz, L. and Español, I. (2009) El paisaje. De la percepción a la gestión (Liteam, Madrid).

Lasso de la Vega, M. (2007) Quintas de recreo. Las casas de campo de la aristocracia alrededor de Madrid, 2 vol. (Madrid City Council, Madrid).

Martínez, A. (2008) El entorno urbano del Palacio Real de Madrid entre 1735 y 1885 (Madrid City Council, Madrid).

Ortega, J., Martínez, A. and Marín, F. J. (2008) Entre los Puentes del Rey y de Segovia. Secuencias gráficas del río Manzanares (Madrid City Council, Madrid).

Pinto, V. (coord.) (2001) Madrid. Atlas Histórico de la Ciudad, vol. 2 (Lunwerg Editors and Fundación Caja Madrid, Madrid).

Rodríguez, E. J. (2011) 'Naturaleza y ciudad: el paisaje de Madrid visto por los extranjeros', in Cabañas, M., López-Yarto, A. and Rincón, W. (ed.) El arte y el viaje (CSIC, Madrid) 321-337.

Rodríguez E. J. and Sáenz de Tejada, C. (2016) 'Evolution and Permanence of City- 
Countryside Views throughout the Urban Development of a City. Madrid as a Study Case', Procedia Engineering 161, 18791886.

Sorokin, P. and Zimmerman, C. (1929) Principles of rural-urban sociology (Holt, New York).

Terán, F. (2006) En torno a Madrid. Génesis espacial de una región urbana (Autonomous Community of Madrid, Madrid).

Urbano López, B. (2013) 'Naturación urbana, un desafío a la urbanización', Chapingo, serie Ciencias Forestales y del Ambiente 19, 225-236.

Velasco Romera, I. (2010) 'Los nuevos paisajes: la desterritorialización de la memoria', in Cornejo, C., Morán, J. and Prada, J., Ciudad, territorio y paisaje: reflexiones para un debate multidisciplinar (Insto. De Economía, Geografía y Demografía CSIC, Madrid), 469-479.

Wester-Heber, M. (2004) 'Underlying concerns in land-use conflicts-the role of place identity in risk perception', Environmental Science \& Policy 7, 109-116.

Zárate, M. A. (2011) 'Paisajes culturales urbanos, entre la protección y la destrucción', Boletín de la Asociación de Geógrafos Españoles 57, 175-194.

Zoido, F. (2002) 'El paisaje y su utilidad para la ordenación del territorio', in Zoido, F. and Venegas, C. (ed.) Paisaje y ordenación del territorio (Junta de Andalucía, Seville) 2132. 